\title{
Enterocin B, a new bacteriocin from Enterococcus faecium T136 which can act synergistically with enterocin A
}

\author{
Pilar Casaus, ${ }^{1}$ Trine Nilsen, ${ }^{2}$ Luis M. Cintas, ${ }^{1}$ Ingolf F. Nes, ${ }^{2}$ \\ Pablo E. Hernández ${ }^{1}$ and Helge Holo ${ }^{2}$
}

Author for correspondence: Helge Holo. Tel: +4764949468. Fax: +4764941465.

e-mail: helge.holo@ibf.nlh.no

1 Departamento de Nutrición y Bromatología III, Facultad de Veterinaria, Universidad Complutense, 28040-Madrid, Spain

2 Laboratory of Microbial Gene Technology, Agricultural University of Norway, PO Box 5051, N-1432 Ås, Norway

\begin{abstract}
The strain Enterococcus faecium T136 produces two bacteriocins, enterocin A, a member of the pediocin family of bacteriocins, and a new bacteriocin termed enterocin B. The $\mathbf{N}$-terminal amino acid sequences of enterocins $\mathbf{A}$ and $\mathbf{B}$ were determined, and the gene encoding enterocin $B$ was sequenced. The primary translation product was a 71 aa peptide containing a leader peptide of the double-glycine type which is cleaved off to give mature enterocin B of 53 aa. Enterocin B does not belong to the pediocin family of bacteriocins and shows strong homology to carnobacteriocin A. However, sequence similarities in their leader peptides and C-termini suggest that enterocin B and carnobacteriocin A are related to bacteriocins of the pediocin family. Enterocins A and B had only slightly different inhibitory spectra, and both were active against a wide range of Gram-positive bacteria, including listeriae, staphylococci and most lactic acid bacteria tested. Both had bactericidal activities, but survival at a frequency of $10^{-4}-10^{-2}$ was observed when sensitive cultures were exposed to either bacteriocin. The number of survivors was drastically reduced when a mixture of the two bacteriocins was added to the cells.
\end{abstract}

Keywords: synergistic bacteriocins, Enterococcus faecium

\section{INTRODUCTION}

Bacteriocins are antimicrobial proteins or peptides that are usually inhibitory only to strains closely related to the producing bacteria. Many bacteriocins from Grampositive bacteria have fairly broad inhibitory spectra, and these bacteriocins may therefore have an applied potential as antimicrobial agents. In particular, bacteriocins from lactic acid bacteria have become attractive as natural food preservatives. Lactic acid bacteria have been used in food and feed preservation for centuries, and their preservative effects are mainly due to the formation of large amounts of lactic acid. This is not always sufficient to prevent bacterial spoilage or outgrowth of pathogenic bacteria, but bacteriocinproducing lactic acid bacteria may serve as a replacement for chemical preservatives in foods (Daeschel, 1989). The broad spectrum bacteriocins from lactic acid bacteria that have been characterized are all small $(2.5-6 \mathrm{kDa})$, heat stable, hydrophobic and cationic

The GenBank accession number for the nucleotide sequence reported in this paper is U87997. peptides (Klaenhammer, 1993). The best studied is nisin, which is produced by strains of Lactococcus lactis (Gross \& Morell, 1971). This bacteriocin is approved as a food additive in many countries, and its efficiency in preventing the growth of spoilage bacteria has been proven in a number of food systems (Delves-Broughton, 1990). Another commercial bacteriocin is pediocin PA1, produced by Pediococcus acidilactici PAC 1.0 (González \& Kunka, 1987). This bacteriocin does not have as broad an inhibitory spectrum as nisin but it is very active against the food-borne pathogen Listeria monocytogenes, which is usually not very sensitive to nisin (Benkerroum \& Sandine, 1988; de Vos et al., 1993). Pediocin PA-1 belongs to the pediocin family of bacteriocins, identified by conserved amino acid sequences particularly in the $\mathrm{N}$-terminal part of the molecule. Bacteriocins belonging to this family are produced by several genera of lactic acid bacteria, and they are all very active against listeriae (Lozano et al., 1992; Aymerich et al., 1996).

Application studies have, however, shown that there are limitations to the usefulness of bacteriocins as antimicrobial agents. Nisin is unstable at $\mathrm{pH}>5$, and 
although bacteriocins of the pediocin family are able to extend the shelf-life of food products, full suppression of the spoilage microflora is rarely achieved (Pucci et al., 1988; Schillinger et al., 1991). Most of the bacteriocins that have been studied appear to inhibit the target cells by causing permeabilization of the cell membrane. For non-lantibiotic bacteriocins such as lactococcin $A$ and pediocin PA-1, the involvement of specific membranebound receptors has been inferred from the findings that liposomes are not affected (van Belkum et al., 1992; Chikindas et al., 1993). Complete elucidation of the primary structure of the various bacteriocins can give insight into structure-function relationships and possibly enable us to construct even more efficient bacteriocins.

In this work, we describe enterocin B. This is a new bacteriocin with a broad spectrum of inhibition that acts synergistically with enterocin A, a member of the pediocin family.

\section{METHODS}

Isolation and characterization of the bacteriocin-producing strain. Lactic acid bacteria were isolated from Spanish dryfermented sausages, manufactured with no added starter cultures, and screened for antimicrobial activity using Lactobacillus sake FVM 148 and List. monocytogenes Scott A as indicators as described previously (Cintas et al., 1995). The isolate T136 was selected for further studies because of its strong inhibitory activity against both these indicators. The strain was examined according to Schleifer \& Kilpper-Bälz (1984) and further tested for arginine dihydrolase activity, Voges-Proskauer reaction (acetoin production), growth on media containing $0.04 \%$ sodium azide (Bacto E V A broth; Oxoid), urease activity and haemolysis on $5 \%$ calf-blood agar plates (Oxoid) as proposed by Devriese et al. (1993). Fermentation patterns were determined with API Rapid $\mathrm{CH}$ fermentation strips (BioMérieux). Total proteins were analysed by SDS-PAGE and the pattern obtained was compared with those of reference strains described by Kersters \& de Ley (1975) and Pot et al. (1994) by B. Pot, University of Ghent, Belgium.

Purification of enterocins A and B. Enterocins A and B were purified from a 21 culture of Enterococcus faecium T136 grown for $18 \mathrm{~h}$ in MRS broth (Difco) at $30^{\circ} \mathrm{C}$ in a fermenter kept at $\mathrm{pH} 5.7$ by the addition of $6 \mathrm{M}$ sodium hydroxide. The cells were removed by centrifugation and $40 \mathrm{~g}$ Amberlite XAD-16 (Supelco) was added to the supernatant. The matrix was washed and the bacteriocin activity was eluted as described by Håvarstein et al. (1994). The eluate was subjected to cation-exchange chromatography followed by hydrophobic interaction chromatography and reverse-phase chromatography as described by Aymerich et al. (1996).

Amino acid sequencing. The $\mathrm{N}$-terminal amino acid sequences were determined by Edman degradation with an Applied Biosystems 477A automatic sequencer with an on-line $120 \mathrm{~A}$ phenylthiohydantoin amino acid analyser, as described previously by Cornwell et al. (1988).

Mass spectrometry. Determination of the molecular mass of enterocin B was performed at the Institut für Organisch Chemie, Eberhard-Karls-Universität Tübingen, Germany, with an electrospray-ionizing mass spectrometer, API III TAGA 6000E (CIEX).

Bacteriocin assays. Bacteriocin activity was quantified using the microtitre plate assay (Holo et al., 1991). Each well in the microtitre plate contained in $200 \mu \mathrm{l}$ MRS broth ( $\mathrm{pH} 6.5$ ) bacteriocin fractions at twofold dilution and the indicator organism $\left(10^{4}\right.$ times dilution of an overnight culture). The microtitre plate cultures were incubated overnight $(16-20 \mathrm{~h})$ at $30^{\circ} \mathrm{C}$, after which growth inhibition of the indicator organism was measured spectrophotometrically at $600 \mathrm{~nm}$ by using a Dynatech Microplate Reader. One bacteriocin unit was defined as the amount of bacteriocin causing $50 \%$ growth inhibition $(50 \%$ of the turbidity of the control culture without bacteriocin) in this assay.

Minimal inhibitory concentration (MIC) values were determined using the method described by Cintas et al. (1995). Concentrations of purified enterocin A and enterocin B were determined spectrophotometrically at $280 \mathrm{~nm}$.

The bactericidal effects of enterocin A and enterocin B were studied by the following assay. Overnight cultures of Enterococcus faecalis EF and Lact. sake NCDO 2714 were diluted 100 times in MRS. Bacteriocin was added and the cultures were incubated at $30^{\circ} \mathrm{C}$. Viable counts were determined by plating on MRS agar plates.

PCR and DNA sequencing. DNA was isolated from E. faecium T136 by the method of Anderson \& McKay (1983). Restriction enzymes and other DNA modifying enzymes were used as recommended by the manufacturers. The sequence of the ent $B$ gene was determined by sequencing PCR products obtained with the primers shown in Table 1 . Amplification reactions were carried out with the Gene Amp PCR kit in a DNA thermal cycler according to the supplier's (Perkin Elmer Cetus) instructions. PCR products were purified by agarose gel electrophoresis and extracted with the Qiaex II gel extraction kit (Qiagen). Primers ENTB1 and ENTB2 (see Table 1) were used in PCR to amplify a 92 bp fragment which was treated with the Klenow fragment of DNA polymerase I to generate blunt ends. Other blunt-ended DNA fragments were obtained by digesting E. faecium T136 DNA with DraI, HincII and SspI. They were all ligated to plasmid vector Bluescript SK II

Table 1. PCR primers used in this study

\begin{tabular}{|ll|}
\hline Primer & \multicolumn{1}{c|}{ Sequence } \\
\hline ENTB1 & 5'-AAY GAY CAY MGN ATG CC-3' \\
ENTB2 & 5'-AAN ARN CCN CCN GCG AT-3' \\
ENTB3 & 5'-AGA CCT AAC AAC TTA TCT AAA G-3' \\
ENTB5 & 5'-GTT GCA TTT AGA GTA TAC ATT TGC-3' \\
ENTB6 & 5'-CTC CAC CGA TAA TTT GTT TCA TCT CTT TCG-3' \\
SK2 (biotinylated) & 5'-CCG CTC TAG AAC TAG TGG ATC-3' \\
\hline
\end{tabular}


(Stratagene) cut with HincII. The ligation mixtures served as templates for the generation of biotinylated PCR products using entB-specific primers in combination with the biotinylated SK2 primer. Single-stranded DNA for DNA sequencing was obtained with the Dynabead M-280 Streptavidin kit and the magnetic separator Dynal-MPC-E1. The Sequenase 2.0 system (USB) was used in the sequence reactions. Analyses of DNA and protein sequences were performed using the Sequence Analysis Software Package (version 8) (Devereux et al., 1984) licensed from the Genetics Computer Group, University of Wisconsin, Madison, USA.

\section{RESULTS}

\section{Identification of $E$. faecium T136}

The enterocins A and B producing isolate T136 described in this work was identified as E. faecium by the following criteria (Devriese et al., 1993): a catalasenegative, Gram-positive, facultatively anaerobic coccus with the ability to grow at 10 and $45^{\circ} \mathrm{C}$ in media containing $6.5 \% \mathrm{NaCl}$, at $\mathrm{pH} 9.6$, and in the presence of both $40 \%(\mathrm{v} / \mathrm{v})$ bile and $0.04 \%$ sodium azide. It did not produce gas from glucose, gave a positive VogesProskauer reaction and produced ammonia from arginine. The final $\mathrm{pH}$ in glucose broth was $4 \cdot 4$, and acid was produced from ribose and L-arabinose, but not from glycogen, D-arabitol, sorbitol or gluconate. The strain did not show urease activity and it was nonhaemolytic on calf-blood agar. This identification was supported by comparison of its SDS-PAGE protein pattern with a database of protein patterns from lactic acid bacteria according to Kersters \& de Ley (1975) and Pot et al. (1994).

\section{Characterization of enterocins A and B}

The supernatant from a culture grown in a fermenter at $\mathrm{pH} 5.7$ was used for the isolation of the antimicrobial compounds. The last step in the purification procedure (Table 2), reverse-phase chromatography, revealed two well-separated bacteriocin activities.

By rechromatography on the reverse-phase column, both were purified to homogeneity. Amino acid sequ-

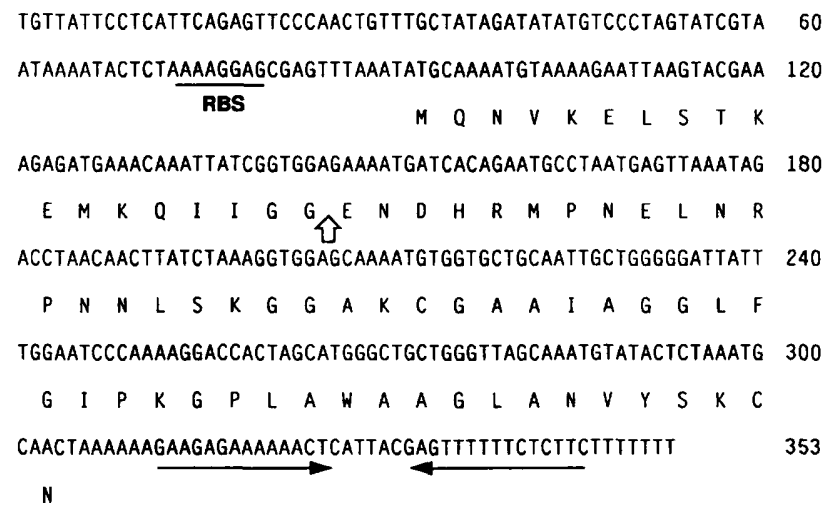

Fig. 1. Nucleotide sequence of the region encoding enterocin $B$ of $E$. faecium T136 and the deduced amino acid sequence. The vertical arrow indicates the processing site of the prepeptide. A putative ribosome-binding site (RBS) is underlined. The horizontal arrows indicate a potential rho-independent transcription terminator sequence.

encing combined with PCR analysis showed that one of the two bacteriocins was identical to enterocin A described previously (Aymerich et al., 1996), while the other was a new bacteriocin, which we have termed enterocin B. By amino acid sequencing we obtained the following sequence: ENDHRMPNELNRPNxLSKGGAKxGAAIAGGLFGIPKGxLAW-. The molecular mass of enterocin B was determined as $5479.0 \pm 1 \cdot 2 \mathrm{Da}$ by mass spectrometry. Enterocin B was found to be a heatstable bacteriocin, and samples of the purified bacteriocin diluted in MRS retained $25 \%$ of their activity after incubation at $100{ }^{\circ} \mathrm{C}$ for $20 \mathrm{~min}$.

\section{Analysis of the gene encoding enterocin B}

Primers based on the partial amino acid sequence of enterocin B were constructed and PCR was used to obtain the DNA sequence of the region encoding enterocin B. Fig. 1 shows the DNA sequence of 353 contiguous nucleotides. Only one open reading frame, $e n t B$, was found in this sequence. The DNA sequencing

\section{Table 2. Purification of enterocins $A$ and $B$}

Bacteriocin activities were determined with P. pentosaceus FBB 63 (enterocin A) and Lact. sake FVM 148 (enterocin B) as indicators.

\begin{tabular}{|c|c|c|c|c|c|c|c|c|}
\hline \multirow[t]{2}{*}{ Purification step } & \multicolumn{4}{|c|}{ Enterocin A } & \multicolumn{4}{|c|}{ Enterocin B } \\
\hline & $\begin{array}{l}\text { Vol. } \\
\text { (ml) }\end{array}$ & $A_{280}$ & $\begin{array}{c}10^{-5} \times \text { Total } \\
\text { activity }(\mathrm{BU})^{*}\end{array}$ & $\begin{array}{l}\text { Yield } \\
(\%)\end{array}$ & $\begin{array}{l}\text { Vol. } \\
\text { (ml) }\end{array}$ & $A_{280}$ & $\begin{array}{c}10^{-5} \times \text { Total } \\
\text { activity }(\mathrm{BU})^{*}\end{array}$ & $\begin{array}{l}\text { Yield } \\
(\%)\end{array}$ \\
\hline Culture supernatant & $2000 \cdot 0$ & & $15 \cdot 0$ & $100 \cdot 0$ & $2000 \cdot 0$ & & 46 & 100 \\
\hline $\mathrm{XAD}-16$ & $250 \cdot 0$ & & $6 \cdot 0$ & $40 \cdot 0$ & $250 \cdot 0$ & & 44 & 95 \\
\hline SP-Sepharose & $50 \cdot 0$ & & $3 \cdot 0$ & $20 \cdot 0$ & $50 \cdot 0$ & & 36 & 79 \\
\hline Octyl-Sepharose & $10 \cdot 0$ & & 0.8 & $5 \cdot 3$ & $10 \cdot 0$ & & 20 & 44 \\
\hline Reverse-phase & $0 \cdot 9$ & $2 \cdot 0$ & 0.7 & $4 \cdot 8$ & $1 \cdot 1$ & 0.57 & 8 & 16 \\
\hline
\end{tabular}

* BU, Bacteriocin unit. 


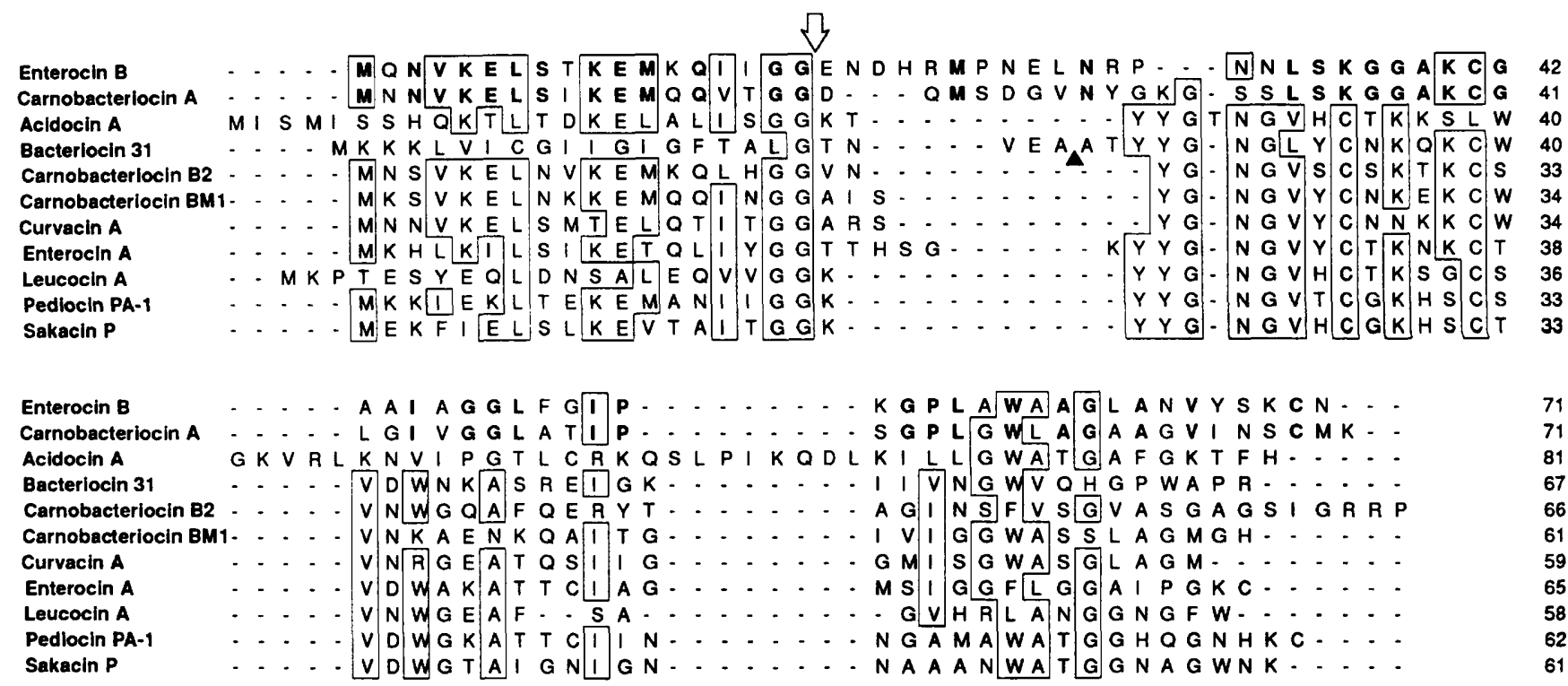

Fig. 2. Alignment of precursor peptides of enterocin B, carnobacteriocin A and bacteriocins of the pediocin family. The arrow indicates the processing site of the bacteriocins with double-glycine leader sequences. The possible processing site for bacteriocin 31 is indicated by $\boldsymbol{\Delta}$. Identical residues in enterocin B and carnobacteriocin A are shown in bold. Sequences were obtained from: carnobacteriocin A (Worobo et al., 1994); acidocin A (Kanatani et al., 1995); bacteriocin 31 (Tomita et al., 1996); carnobacteriocin BM1 and B2 (Quadri et al., 1994); curvacin A (Tichaczek et al., 1993); enterocin A (Aymerich et al., 1996), leucocin A (leucocin A-UAL 187) (Hastings et al., 1991); pediocin PA-1 (Marugg et al., 1992); and sakacin P (Tichaczek et al., 1994).

confirmed the results of the amino acid sequencing and revealed that the bacteriocin is translated as a prebacteriocin of 71 aa which is then processed to give a mature enterocin B of 53 aa. The 18 aa N-terminal extension contains all the consensus elements of a leader peptide of the double-glycine type (Håvarstein et al., 1994). Downstream of entB, two 15 bp inverted repeats separated by 5 bp can establish a stable stem-loop structure with an estimated $\Delta G$ of $-19.8 \mathrm{kcal} \mathrm{mol}^{-1}$ $\left(-82 \cdot 8 \mathrm{~kJ} \mathrm{~mol}^{-1}\right)$. This structure is followed by several $T$ residues and may serve as a rbo-independent transcription terminator (Platt, 1986).

The calculated molecular mass of the 53 aa peptide was $5465 \cdot 2 \mathrm{Da}$ and the $\mathrm{pI}$ was $9 \cdot 49$. The extinction coefficient at $280 \mathrm{~nm}$ was estimated as $7210 \mathrm{M}^{-1} \mathrm{~cm}^{-1}$.

A search for similarity in the nucleotide databases revealed one bacteriocin with strong sequence similarity to enterocin B, carnobacteriocin A (Worobo et al., 1994), which is identical to piscicolin 61 (Holck et al., 1994). Enterocin B and carnobacteriocin A have been aligned in Fig. 2. Both bacteriocins are composed of $53 \mathrm{aa}$ and are $47 \%$ identical at the amino acid level. Their leader peptides both contain 18 residues and share $72 \%$ identity.

\section{Inhibitory spectra of enterocins A and B}

The sensitivity to purified enterocin A and enterocin B of a number of organisms was investigated by a critical dilution assay. Table 3 shows the MIC values obtained with the various test organisms used. None of the bacteriocins were inhibitory to Gram-negative bacteria in this assay (results not shown). However, both bacteriocins were inhibitory to a wide spectrum of Gram-positive bacteria, including spoilage and foodborne pathogens, such as Clostridium sporogenes, Clostridium tyrobutyricum, Propionibacterium spp., List. monocytogenes and Staphylococcus aureus. With only a few exceptions, their inhibitory spectra were similar, and for most of the indicators tested, lower MIC values were observed with enterocin $A$ than with enterocin B. Some strains were only sensitive to one of the enterocins. Pediococcus pentosaceus FBB 63 was sensitive to enterocin A, but not to enterocin B, while Lact. sake FVM 148 was resistant to enterocin A but sensitive to enterocin $\mathrm{B}$.

\section{Enterocins A and B have synergistic activities}

The differences seen in inhibitory spectra between enterocin $A$ and enterocin $B$ suggest that the two bacteriocins have different targets.

To test for synergistic activities between the two bacteriocins, mixtures of enterocin $\mathrm{A}$ and enterocin $\mathrm{B}$ were assayed in the microtitre assay. Using Lact. sake NCDO 2714 as indicator, we did not obtain higher titres by using mixtures than the sum of the titres of the separate bacteriocins, thus no synergism was observed in this assay (results not shown). Enterocins A and B both had bactericidal effects on cultures of sensitive 
Table 3. MICs of enterocin A and enterocin B

\begin{tabular}{|c|c|c|c|c|}
\hline \multirow[t]{2}{*}{ Indicator species* } & \multirow[t]{2}{*}{ Strain } & \multirow[t]{2}{*}{ Source $†$} & \multicolumn{2}{|c|}{ Bacteriocin concn $\left(\mathrm{ng} \mathrm{m}^{-1}\right)$} \\
\hline & & & Enterocin A & Enterocin B \\
\hline Lactobacillus sake & 2714 & NCDO & $0 \cdot 1$ & $0 \cdot 8$ \\
\hline Lactobacillus sake & 148 & FVM & NID & $0 \cdot 4$ \\
\hline Lactobacillus curvatus & 2739 & NCFB & 480 & NID \\
\hline Lactobacillus fermentum & 9338 & ATCC & 810 & 34 \\
\hline Pediococcus pentosaceus & FBB63 & TNO & 610 & NID \\
\hline Enterococcus faecalis & $\mathrm{EF}$ & TNO & 11 & 8 \\
\hline Clostridium sporogenes & $\mathrm{C} 22 / 10$ & TNO & 1000 & 460 \\
\hline Clostridium tyrobutyricum & $3,5 \mathrm{CT}$ & TNO & 1400 & 550 \\
\hline Clostridium tyrobutyricum & 1754 & NCDO & 380 & 140 \\
\hline Clostridium perfringens & 376 & CECT & NID & NID \\
\hline Clostridium botulinum & 551 & CECT & NID & NID \\
\hline Propionibacterium sp. & P4 & TNO & 50 & 90 \\
\hline Propionibacterium sp. & P6 & TNO & 40 & 50 \\
\hline Propionibacterium acidipropionici & 573 & NCDO & 40 & 90 \\
\hline Listeria monocytogenes & 7973 & NCTC & 40 & 150 \\
\hline Listeria monocytogenes & LI5sv1/2 & FVM & 100 & 440 \\
\hline Listeria monocytogenes & 5105 & NCTC & 50 & 200 \\
\hline Listeria monocytogenes & LI1sv4 & FVM & 40 & 160 \\
\hline Listeria monocytogenes & Scott A & FVM & 40 & 140 \\
\hline Listeria innocua & BL86/26 & TNO & 120 & 430 \\
\hline Staphylococcus aureus & 137 & FRI & 530 & 460 \\
\hline Staphylococcus aureus & $196 \mathrm{E}$ & FRI & 580 & 1000 \\
\hline Staphylococcus aureus & 472 & FRI & 1300 & 770 \\
\hline Staphylococcus carnosus & MC1 & TNO & 180 & 410 \\
\hline
\end{tabular}

NID, No inhibition detected at $3.75 \mu \mathrm{g}$ enterocin $\mathrm{A} \mathrm{ml}^{-1}$ or $5.0 \mu \mathrm{g}$ enterocin B ml ${ }^{-1}$.

* Growth media for indicator species: lactic acid bacteria strains, MRS medium (Difco); Clostridium strains, RCM (Oxoid); Propionibacterium spp., GYE medium (Cintas et al., 1995); other strains, BHI medium (Oxoid).

†Source abbreviations: ATTC, American Type Culture Collection (Rockville, MD, USA); CECT, Colección Española de Cultivos Tipo (Valencia, Spain); NCDO and NCFB, National Collection of Food Bacteria (Reading, UK); NCTC, National Collection of Type Cultures (London, UK); TNO, Nutrition and Food Research (Zeist, The Netherlands); FVM, Facultad de Veterinaria (Madrid, Spain); FRI, Food Research Institute (Madison, WI, USA).

strains (Fig. 3). Despite this, a low number of cells survived and were able to grow in the presence of either bacteriocin. However, mutants resistant to one of the two bacteriocins were still sensitive to the other (results not shown). We compared the bactericidal effect of enterocins $A$ and $B$ and mixtures of them. The number of survivors was drastically reduced in cultures treated with both bacteriocins compared to cultures exposed to only enterocin A or B, demonstrating a synergistic effect between the two bacteriocins. In the experiments described in Fig. 3, no survival was observed when a mixture of enterocins $A$ and $B$ was used.

\section{DISCUSSION}

During the last few years, a large number of bacteriocins from lactic acid bacteria have been described at the molecular level (Klaenhammer, 1993). Most are small
$(2 \cdot 5-6 \mathrm{kDa})$, thermostable, hydrophobic and cationic peptides, and enterocin B falls into this category. Our results indicate that enterocin B does not contain modified amino acids. The molecular mass found by mass spectrometry was $14 \mathrm{Da}$ higher than that calculated from the amino acid sequence. This difference can be ascribed to oxidation of the only methionine residue in the bacteriocin and the formation of a disulfide bridge between its two cysteine residues. These modifications are formed spontaneously and have also been observed with synthetic peptide bacteriocins (Fimland et al., 1996). When assayed in the presence of $5 \mathrm{mM}$ dithiothreitol to reduce disulfide bridges, the titre of enterocin $B$ was half of that found in the absence of the thiol compound (results not shown). This finding supports the idea of a disulfide bridge between Cys- 23 and Cys- 52 in enterocin B. Similar experiments have been done with pediocin PA-1 (Chikindas et al., 1993) and colicin V 


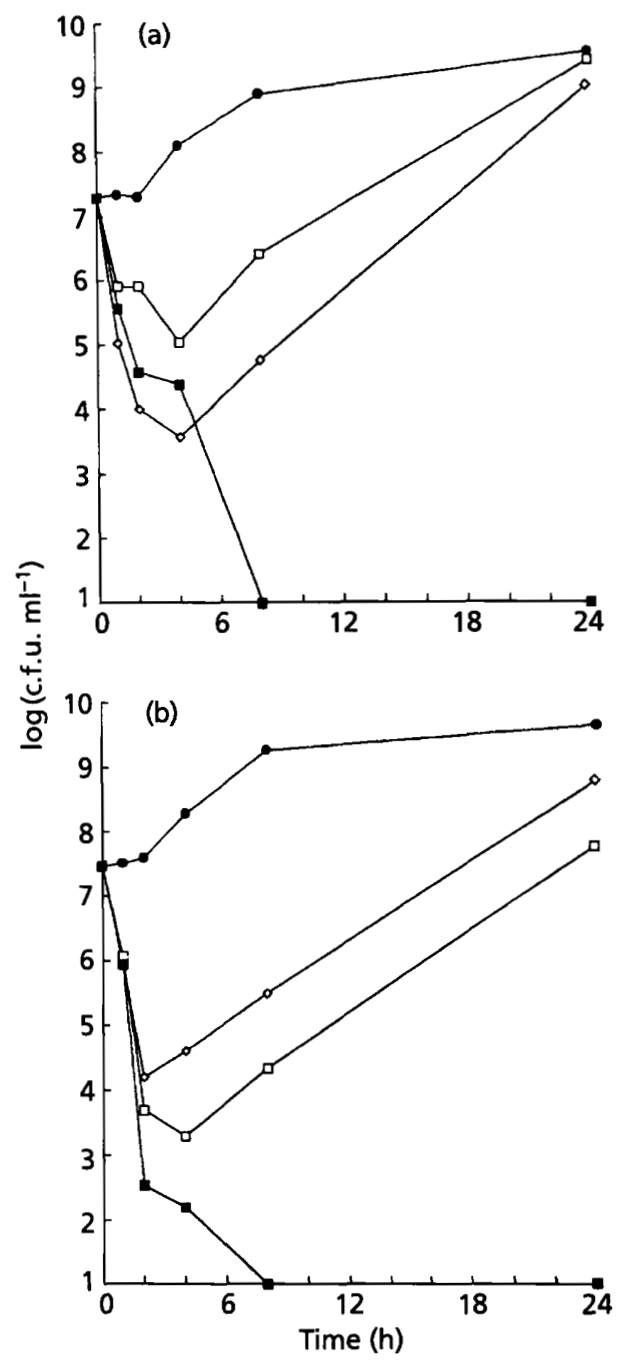

Fig. 3. Killing of E. faecalis EF (a) and Lact. sake NCDO 2714 (b) with purified enterocin $A$ and enterocin B. (a) $\square$, Enterocin A $\left(41 \mathrm{ng} \mathrm{ml}^{-1}\right) ; \diamond$, enterocin B $\left(190 \mathrm{ng} \mathrm{ml}^{-1}\right) ;$, enterocin A (21 $\left.\mathrm{ng} \mathrm{ml}^{-1}\right)$ +enterocin B $\left(95 \mathrm{ng} \mathrm{ml}^{-1}\right) ; 0$, no bacteriocin. (b) $\square$, Enterocin $A\left(16 \mathrm{ng} \mathrm{ml}^{-1}\right) ; \diamond$, enterocin $B\left(173 \mathrm{ng} \mathrm{ml}^{-1}\right) ; \square$, enterocin $A\left(8 \mathrm{ng} \mathrm{ml}^{-1}\right)$ +enterocin $B\left(87 \mathrm{ng} \mathrm{ml}^{-1}\right) ; O$, no bacteriocin.

(Håvarstein et al., 1994). In both these cases, the activity was decreased when the Cys residues were in the reduced state.

Despite their physico-chemical similarities, there is a remarkable lack of sequence similarity among most of the bacteriocins from lactic acid bacteria (Klaenhammer, 1993). The pediocin family is the only grouping that has been identified by sequence similarities, and bacteriocins of this family all contain the motif YGNGVxC in the $\mathrm{N}$ terminal part (Lozano et al., 1992; Aymerich et al., 1996). Enterocin B does not contain this motif. However, homology was found to carnobacteriocin A (Worobo et al., 1994), also described as piscicolin 61 (Holck et al., 1994). Enterocin B and carnobacteriocin A are $47 \%$ identical. To our knowledge, this is the first report on two non-lantibiotic bacteriocins from lactic acid bac- teria with strong sequence similarity outside the pediocin family of bacteriocins.

The gene encoding bacteriocin immunity is usually located immediately downstream of, and in the same operon as, the structural gene for non-lantibiotics of lactic acid bacteria. Enterocin B and carnobacteriocin A are exceptions to this rule. In both cases, the bacteriocin gene is followed by a putative rbo-independent terminator. Genes encoding immunity to enterocin B or carnobacteriocin A have not been identified, but according to Worobo et al. (1994) the genes for carnobacteriocin A production and immunity are located on the same $5.4 \mathrm{~kb}$ restriction fragment of the bacteriocin plasmid.

Despite the absence of the YGNGVxC motif, enterocin $B$ shares sequence similarities with members of the pediocin family. Its 18 aa leader peptide has the same size as, and $50 \%$ or more sequence identity to, the leader peptide of carnobacteriocin A and most members of the pediocin family (Fig. 2). Furthermore, the $16 \mathrm{C}$-terminal amino acids of pediocin PA-1 are $42 \%$ identical $(54 \%$ similar) to the corresponding residues in enterocin B. The sequence alignment of the prepeptides of enterocin $B$, carnobacteriocin $A$ and pediocin-like bacteriocins revealed that consensus residues, including a GWAxG motif, are shared between the two groups of bacteriocins in their C-terminal parts.

It is tempting to speculate that the conserved residues in the C-terminal region reflect structure-function relationships. Fimland et al. (1996) showed that the C-terminal part of the pediocin-like bacteriocins is of importance for their activity. It is interesting to note that leucocin AUAL 87, which lacks some of the consensus residues in the C-terminal part of the molecule, has bacteriostatic but no bactericidal activity (Stiles, 1994).

Enterocins A and B both have broad and very similar inhibitory spectra. From an applied point of view, it is interesting that both are able to inhibit food-borne and pathogenic species like List. monocytogenes, C. tyrobutyricum and $S$. aureus. Since enterocin B was inhibitory to a few strains that were insensitive to enterocin $\mathrm{A}$, we hypothesized that the two bacteriocins could have differences in their mode of action and therefore may act synergistically. Two assays were used to test for synergism. In the critical dilution assay, the bacteriocin concentration causing $50 \%$ growth inhibition can be determined, but the level of inhibition at other bacteriocin concentrations is not determined. No synergism between enterocins A and B was observed in this assay. Because the bactericidal effect of neither bacteriocin was complete, we could investigate synergism at higher bacteriocin concentrations by measuring the survival of cells exposed to the bacteriocins. At concentrations at which most of the cells were killed, the synergistic bactericidal effects of enterocins A and B were clearly demonstrated, and the number of survivors was reduced by several orders of magnitude when a mixture of the two bacteriocins was used. 
Typically, a 3-4 log reduction in c.f.u. is obtained by exposing a sensitive culture to pediocin-like bacteriocins (Chikindas et al., 1993; Rekhif et al., 1994; Schillinger $e t$ al., 1991). The survivors from exposure to high concentrations of bacteriocins belonging to the pediocin family remain resistant to the bacteriocin (Rekhif et al., 1994), but the survivors of exposure to enterocin A had not acquired resistance to enterocin B (results not shown). Thus a likely explanation of the reduced survival obtained by exposing a culture to both bacteriocins is that enterocin $B$ is able to kill the bacteria that survive enterocin A treatment.

Our findings may be important from an applied point of view. In food preservation, the combined use of enterocin A and enterocin B is likely to be better than using a pediocin-like bacteriocin alone to prevent growth of spoilage bacteria. As a starter culture for food fermentation, E. faecium T136 has the advantage that it produces both these bacteriocins.

\section{ACKNOWLEDGEMENTS}

We thank B. Pot for his help in the identification of strain $\mathrm{T} 136, \mathrm{~K}$. Sletten for performing amino acid sequencing and J. Metzger for mass spectrometry measurements. This work was partially supported by grant ALI94-1026 from the Comisión Interministerial de Ciencia y Tecnología, Spain, and the Commission of European Communities (Contract Biot-CT9403055). P.C. is recipient of a grant from the Ministerio de Educación y Ciencia, Spain. L.M.C. is recipient of a postdoctoral Biotechnology Research Training grant from the Commission of the European Communities. T.N. was funded by The Nordic Industrial Fund grant P93154. H.H. was supported by grants from The Norwegian Dairies Association, Oslo, Norway.

\section{REFERENCES}

Anderson, D. G. \& McKay, L. L. (1983). Simple and rapid method for isolating large plasmid DNA from lactic streptococci. Appl Environ Microbiol 46, 549-552.

Aymerich, T., Holo, H., Håvarstein, L. S., Hugas, M., Garriga, M. \& Nes, I. F. (1996). Biochemical and genetic characterization of enterocin A from Enterococcus faecium, a new antilisterial bacteriocin in the pediocin family of bacteriocins. Appl Environ Microbiol 62, 1676-1682.

van Belkum, M. J., Kok, J., Venema, G., Holo, H., Nes, I. F., Konigs, W. N. \& Abee, T. (1992). The bacteriocin lactococcin A specifically increases permeability of lactococcal cytoplasmic membranes in a voltage-independent, protein-mediated manner. J Bacteriol 173, 7934-7941.

Benkerroum, N. \& Sandine, W. E. (1988). Inhibitory action of nisin against Listeria monocytogenes. J Dairy Sci 71, 3237-3245.

Chikindas, M. L., Garcla-Garcerà, M. J., Driessen, A. J. M., Ledeboer, A. M., Nissen-Meyer, J., Nes, I. F., Abee, T., Konings, W. N. \& Venema, G. (1993). Pediocin PA-1, a bacteriocin from Pediococcus acidilactici PAC1.0, forms hydrophilic pores in the cytoplasmic membrane of target cells. Appl Environ Microbiol 59, 3577-3584.

Cintas, L. M., Rodríguez, J. M., Fernández, M. F., Sletten, K., Nes, I. F., Hernández, P. E. \& Holo, H. (1995). Isolation and characteriza- tion of pediocin L50, a new bacteriocin from Pediococcus acidilactici with a broad inhibitory spectrum. Appl Environ Microbiol 61, 2643-2648.

Cornwell, G. G., Sletten, K., Johansson, B. \& Westermark, P. (1988). Evidence that the amyloid fibril protein in senile systemic amyloidosis is derived from normal prealbumin. Biochem Biophys Res Commun 154, 648-653.

Daeschel, M. A. (1989). Antimicrobial substances from lactic acid bacteria for use as food preservatives. Food Technol 43, 164-167.

Delves-Broughton, J. (1990). Nisin and its use as a food preservative. Food Technol 44, 100-117.

Devereux, J. P., Haeberli, P. \& Smithies, O. (1984). A comprehensive set of sequence analysis programs for the VAX. Nucleic Acids Res 12, 387-395.

Devriese, L. A., Pot, B. \& Collins, M. D. (1993). Phenotypic identification of the genus Enterococcus and differentiation of phylogenetically distinct enterococcal species and species groups. J Appl Bacteriol 75, 399-408.

Fimland, G., Blingsmo, O. R., Sletten, K., Jung, G., Nes, I. F. \& Nissen-Meyer, J. (1996). New biologically active hybrid bacteriocins constructed by combining regions from various pediocin-like bacteriocins : the C-terminal region is important for determining specificity. Appl Environ Microbiol 62, 3313-3318.

González, C. F. \& Kunka, B. S. (1987). Plasmid-associated bacteriocin production and sucrose fermentation in Pediococcus acidilactici. Appl Environ Microbiol 53, 2534-2538.

Gross, E. \& Morell, J. L. (1971). The structure of nisin. J Am Chem Soc 93, 4634-4635.

Hastings, J. W., Sailer, M., Johnson, K., Roy, K. L., Vederas, J. C. \& Stiles, M. E. (1991). Characterization of leucocin A-UAL 187 and cloning of the bacteriocin gene from Leuconostoc gelidum. J Bacteriol 173, 7491-7500.

Håvarstein, L. S., Holo, H. \& Nes, I. F. (1994). The leader peptide of colicin $\mathrm{V}$ shares consensus sequences with leader peptides that are common amongst peptide bacteriocins produced by Grampositive bacteria. Microbiology 140, 2383-2389.

Holck, A., Axelsson, L. \& Schillinger, U. (1994). Purification and cloning of piscicolin 61, a bacteriocin from Carnobacterium piscicola LV61. Curr Microbiol 29, 63-68.

Holo, H., Nilssen, Ø. \& Nes, I. F. (1991). Lactococcin A, a new bacteriocin from Lactococcus lactis subsp. cremoris: isolation and characterization of the protein and its gene. J Bacteriol 173, 3879-3887.

Kanatani, K., Oshimura, M. \& Sano, K. (1995). Isolation and characterization of acidocin $\mathrm{A}$ and cloning of the bacteriocin gene from Lactobacillus acidophilus. Appl Environ Microbiol 61, 1061-1067.

Kersters, K. \& de Ley, J. (1975). Identification and grouping of bacteria by numerical analysis of their electrophoretic protein patterns. J Gen Microbiol 87, 333-342.

Klaenhammer, T. R. (1993). Genetics of bacteriocins produced by lactic acid bacteria. FEMS Microbiol Rev 12, 224-227.

Lozano, J. C. N., Nissen-Meyer, J., Sletten, K., Peláez, C. \& Nes, I. F. (1992). Purification and amino acid sequence of a bacteriocin produced by Pediococcus acidilactici. J Gen Microbiol 138, 1985-1990.

Marugg, J. D., González, C. F., Kunka, B. S., Ledeboer, A. M., Pucci, M. J., Toonen, M. Y., Walker, S. A., Zoetmulder, L. C. M. \& Vandenbergh, P. A. (1992). Cloning, expression and nucleotide sequence of genes involved in production of pediocin PA-1, a bacteriocin from Pediococcus acidilactici PAC 1.0. Appl Environ Microbiol 58, 2360-2367. 
Platt, T. (1986). Transcription termination and regulation of gene expression. Annu Rev Biochem 55, 1822-1828.

Pot, B., Vandamme, P. \& Kersters, K. (1994). Analysis of electrophoretic whole-organism protein fingerprints. In Chemical Methods in Prokaryotic Systematics, pp. 493-521. Edited by M. Goodfellow \& A. G. O’Donnell. Chichester: J. Wiley.

Pucci, M. J., Vedamuthu, E. R., Kunka, B. S. \& Vandenbergh, P. A. (1988). Inhibition of Listeria monocytogenes by using bacteriocin pediocin PA-1 produced by Pediococcus acidilactici PAC1.0. Appl Environ Microbiol 54, 2349-2353.

Quadri, L. E. N., Sailers, M., Roy, K. L., Vederas, J. C. \& Stiles, M. E. (1994). Chemical and genetic characterization of bacteriocins produced by Carnobacterium piscicola LV17B. J Biol Chem 269, 12204-12211.

Rekhif, N., Atrih, A. \& Lefebvre, G. (1994). Selection and properties of spontaneous mutants of Listeria monocytogenes ATCC 15313 resistant to different bacteriocins produced by lactic acid bacteria strains. Curr Microbiol 28, 237-241.

Schillinger, U., Kaya, M. \& Lucke, F. K. (1991). Behaviour of Listeria monocytogenes in meat and its control by a bacteriocin producing strain of Lactobacillus sake. J Appl Bacteriol 70, 473-478.

Schleifer, K. H. \& Kilpper-Bälz, R. (1984). Transfer of Streptococcus faecalis and $S$. faecium to the genus Enterococcus nom. rev. as Enterococcus faecalis comb. nov. and Enterococcus faecium comb. nov. Int J Syst Bacteriol 34, 31-34.
Stiles, M. E. (1994). Bacteriocins produced by Leuconostoc species. In Bacteriocins of Lactic Acid Bacteria. Microbiology, Genetics and Applications, pp. 497-506. Edited by L. DeVuyst \& E. C. Vandamme. London: Blackie Academic and Professional.

Tichaczek, P. S., Vogel, R. F. \& Hammes, W. P. (1993). Cloning and sequencing of curA encoding curvacin A, the bacteriocin produced by Lactobacillus curvatus LTH1174. Arch Microbiol 160, 279-283.

Tichaczek, P. S., Vogel, R. F. \& Hammes, W. P. (1994). Cloning and sequencing of $s a k P$ encoding sakacin $\mathrm{P}$, the bacteriocin produced by Lactobacillus sake LTH 673. Microbiology 140, 361-367.

Tomita, H., Fujimoto, S., Tanimoto, K. \& Ike, Y. (1996). Cloning and genetic organization of the bacteriocin 31 determinant encoded on the Enterococcus faecalis pheromone-responsive conjugative plasmid pYI17. J Bacteriol 78, 3585-3593.

de Vos, W. M., Mulders, J. W. M., Siezen, R. J., Hugenholtz, J. \& Kuipers, O. P. (1993). Properties of nisin $Z$ and distribution of its gene, nisZ, in Lactococcus lactis. Appl Environ Microbiol 59, 213-218.

Worobo, R. W., Henkel, T., Sailer, M., Roy, K. L., Vederas, J. C. \& Stiles, M. E. (1994). Characteristics and genetic determinant of a hydrophobic peptide bacteriocin, carnobacteriocin A, produced by Carnobacterium piscicola LV17A. Microbiology 140, 517-526.

Received 23 December 1996; revised 24 February 1997; accepted 7 March 1997. 